Article

\title{
Property Arrangements and Soy Governance in the Brazilian State of Mato Grosso: Implications for Deforestation-Free Production
}

\author{
Lisa L. Rausch ${ }^{1, *}$ and Holly K. Gibbs ${ }^{1,2}$ \\ 1 Center for Sustainability and the Global Environment (SAGE), Nelson Institute for Environmental Studies, \\ University of Wisconsin-Madison, 1710 University Ave., Madison, WI 53726, USA \\ 2 Department of Geography, University of Wisconsin, 550 N. Park Street, Madison, WI 53706, USA; \\ hkgibbs@wisc.edu \\ * Correspondence: llrausch@wisc.edu; Tel.: +1-608-890-0037
}

Academic Editor: H. Ricardo Grau

Received: 6 November 2015; Accepted: 11 March 2016; Published: 24 March 2016

\begin{abstract}
The production of soy is one of the most important economic activities in the Brazilian Amazon, though the expansion of this industry has come at the cost of huge swaths of forest. Since 2006, the private firms that buy and trade soybeans globally have assumed a key role in ensuring that soy producers comply with forest protection policies, including the Soy Moratorium and public policies banning the use of illegally deforested land. We used evidence from field interviews and a GIS of property boundaries and soy-production areas to describe the private sector governance process and to characterize the variety of property arrangements underlying soy production in Mato Grosso, the leading soy-producing state in the Brazilian Amazon. These increasingly complex property arrangements include ownership of multiple properties by a single producer, use of rental properties owned by others, and soy and cattle production on a single property. This complexity could create loopholes allowing soy associated with deforestation to enter the supply chain. Comprehensive soy-governance strategies that include more robust procedures for verifying the provenance of soy across all properties, that account for the entire property rather than only the area planted to soy, and that use more transparent verification systems could achieve greater reductions in deforestation.
\end{abstract}

Keywords: Brazil; Amazon; land holdings; soy; deforestation; environmental governance; Soy Moratorium

\section{Introduction}

Soy production is one of the most important economic activities in the Brazilian Amazon, where it is mechanized and takes place at industrial scales. Since 2001, soy production in the states comprising the Legal Amazon has more than tripled (from 10,340 MT to 31,656 MT) [1]. In Mato Grosso, the Brazilian Amazon's most important soy-producing state, receipts from agriculture accounted for approximately 29 percent of the GDP in 2012, with much of this value derived from activities supporting the production of soybeans [2]. The economic value of agriculture in the region also extends beyond that sector; nearly half of Mato Grosso's growth in non-agricultural GDP between 2001 and 2010 can be linked to agriculture [3].

Expansion of industrial soybean production, along with ranching, also contributed to alarming rates of deforestation in the Brazilian Amazon during the mid-2000s [4,5]. Brazil's expanding soy fields have most commonly replaced pasture, but up to 30 percent of new fields were created through forest conversion in the last decade $[4,6]$. However, a combination of public and private sector efforts enacted in the Brazilian Amazon since the mid-2000s helped decrease deforestation for soy to nearly zero 
by 2014 [6-9]. Effective environmental governance within the soy sector is especially important for protecting forests because the economic importance of soy production makes its continued expansion likely $[10,11]$.

A handful of basic policies underlie the public environmental governance relevant to soy production in the Brazilian Amazon. First, the Brazilian government has increased enforcement of forest protection laws, beginning in 2004 with its Plan to Prevent and Control Deforestation in the Amazon (Portuguese acronym PPCDAM) [12], and more recently with revisions to the federal Forest Code (law 12615/2012), which establishes how much of each rural property can be lawfully cleared. Environmentalists and researchers have criticized the updated Forest Code for reducing the amount of forests protected on private properties overall, though the law's introduction of a national environmental registry of rural properties, known by its Portuguese acronym CAR, is expected to serve as an important forest conservation tool by supporting better monitoring of land use on private properties [13]. Under the Forest Code, deforestation may continue legally in some cases [13], though most ongoing deforestation on soy farms is likely illegal because it exceeds prescribed set-asides [6]. Properties or parts of properties with unlawful deforestation identified by Brazil's environmental police (known by its Portuguese acronym, IBAMA) are fined and placed on a public record of embargoed properties [14,15]. Federal law prohibits economic activities on embargoed areas, including producing, buying, and selling products originating from these areas (Decree 6514/2008). These policies apply to all rural properties in the Amazon, including those with soy production.

Soy-specific efforts to control deforestation also emerged from the private sector and from civil society during the same period. Most importantly, in 2006, globally positioned commodity traders, such as ADM, Bunge, Cargill, and others, who collectively purchase around 90 percent of the soy produced in the Brazilian Amazon, agreed to impose a moratorium on deforestation for the production of soybeans in the Amazon biome [16,17]. This market-based intervention, known as the Soy Moratorium, was initiated by international environmental organizations (commonly called NGOs) led by Greenpeace, which collaborated with retailers to pressure traders to implement new purchase criteria for their suppliers $[18,19]$. Under the Soy Moratorium, originally signed for a two-year period and subsequently renewed several times, traders will not purchase soybeans grown on areas in the Brazilian Amazon that were cleared after July 2006 (changed to July 2008 in the 2014 renewal), even if the area could be cleared legally under the Forest Code [20] Specifically, they reject soy linked to deforestation according to a satellite monitoring system managed by the Soy Moratorium Working Group comprised of traders, NGOs, and government agencies [21]. The monitoring system detects crop production on fields deforested after 2006 using MODIS imagery overlaid with polygons of annual deforestation identified by the Brazilian Space Agency's PRODES maps [5]. These areas are then examined further, using manual interpretation of Landsat images and, in the past, aerial flyovers to confirm that soy was truly being grown there [22]. Field visits determine the identity of the responsible producer or farm, and a list is compiled and provided to the traders that signed the moratorium, which then screen producers against this list at the time of purchase. The aggregate results of the monitoring system are made public each year in a report issued by administrators of the monitoring system, though identifiable information about individual violations is withheld [21]. Beyond the moratorium, soy traders also help discourage illegal deforestation in violation of the Forest Code by excluding soy produced on embargoed areas from their supply chain. The engagement of soy traders with both public and private policies against deforestation in their purchasing processes underlies the private governance of soy production in the Amazon [23].

In their efforts to establish the Soy Moratorium, environmental organizations leveraged economic teleconnections, or links forged among distant places as commodities travel through supply chains to consumers, within the soy supply chain [24]. In this case, teleconnections link soy producers in the Brazilian Amazon with European consumers who purchased 38 percent of the soy produced in the Amazon in 2005 (China has since become the dominant trading partner) [1,25]. The adoption and persistence of the Soy Moratorium for nearly 10 years, through several renewals, reflects the growing 
influence that consumers, retailers, and actors external to supply chains can have on the environmental outcomes of commodity production [26]. In contrast to commonly certified commodities like coffee or chocolate, for which consumers may pay a premium for differentiated production practices or quality [27], soy is an "invisible" product that is rarely consumed directly; instead, soy is used primarily as an ingredient or input in processed foods, meat, and industrial products, so upgrades to production standards are unlikely to be monitizable [28,29]. Thus, the Soy Moratorium commitments reveal the sensitivity of traders to risks to their reputations and to the potential loss of major retailers as customers $[18,30]$; the rapid reduction in deforestation for soy following the agreement illustrates the sensitivity of producers in the Amazon to the risk of being excluded from the market. The Soy Moratorium is set to expire in May 2016. Retailers and soy traders, however, continue to publicly commit to sustainable soy production, though the exact mechanisms of realizing these commitments are still evolving [31-33]. The high global and local stakes for the future of zero-deforestation soy in Brazil and the uniqueness of the present hybrid public and private governance scenario in the sector underscore the importance of deepening our understanding of how this governance works in practice [34].

In this paper, we describe challenges to continued guarantees of zero-deforestation soy under the present governance or under future governance regimes that may follow the end of the Soy Moratorium. We present data from surveys conducted with producers and from interviews of other soy stakeholders in key soy-production regions of Mato Grosso, documenting complex property arrangements that challenge the verification systems used by soy traders. We do this by considering the unit at which individual soy producers make decisions, which is the total portfolio of properties owned or rented by individual producers, here referred to as property arrangements. We also examine the increasing integration of cattle and soy production on individual properties and within these producer-level property arrangements. Finally, we use these findings to highlight vulnerabilities in the current governance scenario, especially at the point of verification. Mismatches between the complexity of agricultural production systems and soy governance may create risks that soy could once again become associated with Brazilian Amazon deforestation, especially without the comprehensive monitoring of the Soy Moratorium. Accounting for these more complex property arrangements will help to ensure the durability of deforestation-free soy.

\section{Methods and Study Region}

In November of 2013 and July and August of 2014 we surveyed 43 producers and conducted 17 more extensive interviews with key stakeholders in Mato Grosso, the most important soy-producing state in the Brazilian Amazon. The surveys focused on producers operating in three municipalities in Mato Grosso that are presently experiencing rapid expansion of area planted to soybean-São Felix do Araguaia (SFA), Feliz Natal (FN), and Nova Ubiratã (NU) (Figure 1) [35]. All three municipalities extend into the ecologically and culturally important Xingu National Park, and are located in what is considered to be the "arc of deforestation" in the southeastern portion of the Amazon biome, though portions of SFA and NU extend into the Cerrado biome. Properties in SFA are, on average, much larger than properties in the other municipalities, reflective of that municipality's decades-long history of extensive ranching [36]. Extensive land use in FN and NU was more limited until recently; logging is now a major activity in addition to agricultural expansion. All three municipalities have been placed on the Ministry of the Environment's list of "priority" municipalities for their high rates of deforestation since 2008, though FN was removed from this list in 2012 after drastically reducing its deforestation rate and registering a high percent of rural properties in the CAR [37]. Several of our more in-depth interviews also took place in these three municipalities, though insight was also sought from other key informants with experiences in the same region as the survey municipalities; these individuals included producers, municipal officials, representatives of state and federal environmental agencies, soy industry employees, and leaders of producer organizations (further details about interviews are provided in Table 1). In-depth interviews were semi-structured, and varied according to the type 
of stakeholder; topics included the history of soy production in the region, dynamics of the local soy supply chain, relevance of environmental policies in the local context, and expectations for the future of the local agriculture economy. Additionally, we visually inspected embargoed fields located along roads in FN, which we identified using IBAMA's public registry, for evidence of recent crop production [14].

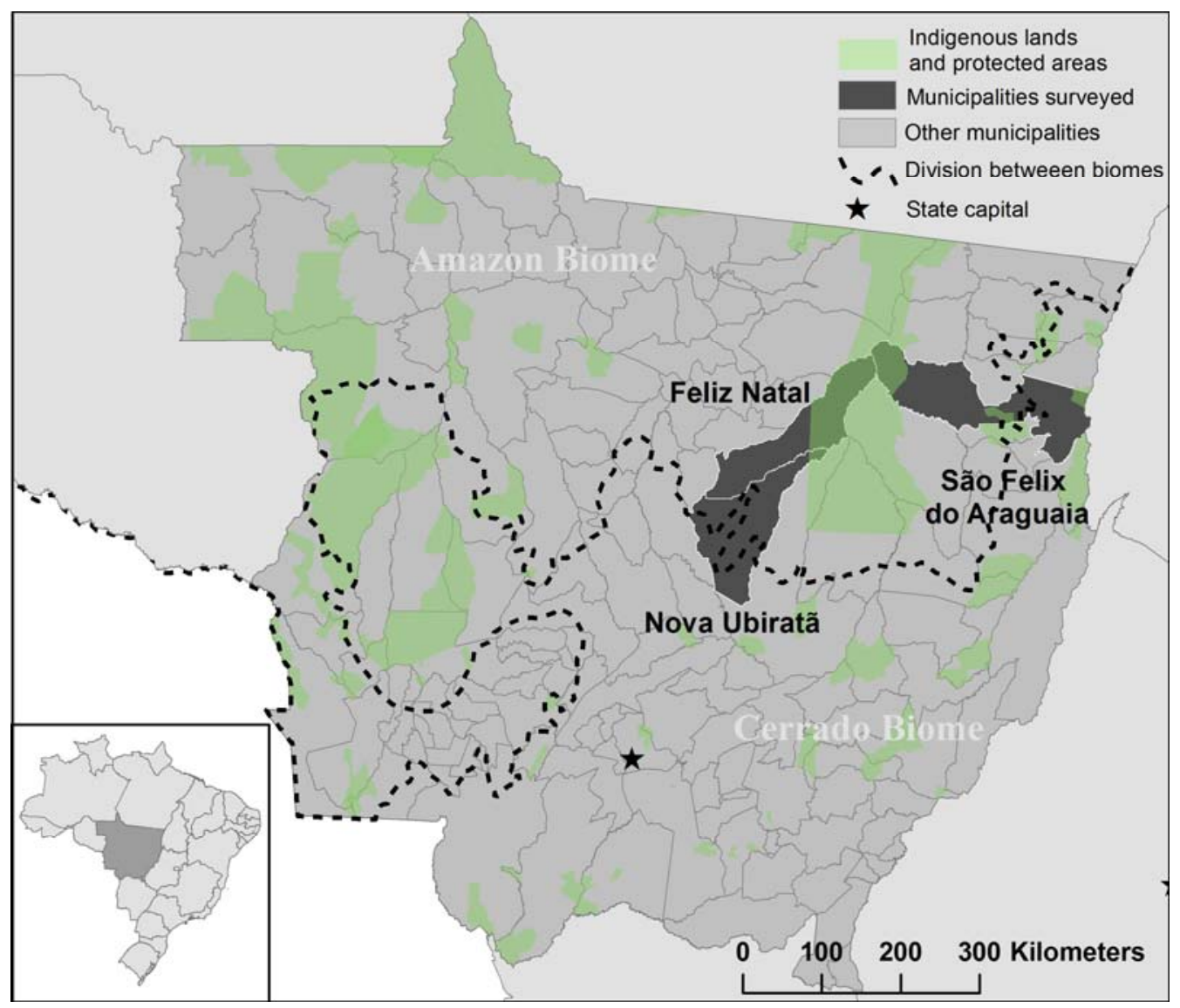

Figure 1. Study Area.

Table 1. Interviews by Date and Type of Informant.

\begin{tabular}{ll}
\hline Dates of Interviews & Type of Respondent \\
\hline & Local NGO rep. with years of experience working with soy farmers \\
& Producers' association representative \\
& Local journalist \\
& Rural syndicate representative \\
& Public attorney for the state of Mato Grosso \\
& Large commodities trader \\
Large soy producer 1 \\
Large soy producer 2 \\
Corporate soy producer \\
Small producer not involved in soy production \\
\hline Municipal Secretary of Environment \\
Rural syndicate representative \\
Large soy producer \\
Large commodity trader \\
Employee 1 in state environmental licensing department (SEMA) \\
Employee 2 in state environmental licensing department (SEMA) \\
Field agent with federal environmental agency (IBAMA) \\
\hline
\end{tabular}


For the producer survey, we employed a non-probabilistic, hybrid criterion- and convenience-based sampling method [38]. A field team surveyed respondents based on property maps that identified soy-producing farms with a 2013 MODIS-based map of soy areas in the Amazon biome [6], and CAR property boundaries downloaded in 2014 from the state environmental agency in Mato Grosso and from the National Institute for Colonization and Agrarian Reform (known by its acronym in Portuguese, Incra) $[39,40]$. The field team then selected properties from the map, attempting to capture a relatively representative sample based on property size, and visited the properties in person in order to apply the survey. Additionally, we were able to identify and survey a couple of soy properties that did not have CAR in each municipality while in the field. Convenience played some role in property selection, and properties nearer to urban centers or more passable roads are likely overrepresented.

Survey questions sought details about producers' land management strategies, and their familiarity and experiences with environmental policies; discussion of related topics accompanied the surveys in many cases, corresponding to the willingness of respondents to converse. Together with the key-informant interviews, these additional conversations with survey respondents helped the field team gain insights into land-use dynamics that were not foreseen when designing the survey. Most of the producers who were approached were receptive to being surveyed. Producers included renters or owners, or their representatives-whoever was responsible for production on the property at the time of the interview. In some cases, responsible parties could not be located on candidate properties; we made return trips within reason to attempt to survey as many soy producers as possible within our study region. The prevalence of multiple property ownership, as well as the fact that we did not have property boundaries for 24 percent of the 2013 soy area [6], make it difficult to precisely estimate the percent of local soy producers captured in the surveys for each municipality; with these caveats, estimates of our sampling rate are provided in Table 2.

Table 2. Soy properties in studied municipalities.

\begin{tabular}{|c|c|c|c|c|}
\hline Municipality & $\begin{array}{c}\text { A: Number of Soy } \\
\text { Properties }^{1}\end{array}$ & $\begin{array}{l}\text { B: Number of } \\
\text { Producers Surveyed }\end{array}$ & $\begin{array}{l}\text { C: Avg. number of } \\
\text { Properties Reported } \\
\text { per Producer }\end{array}$ & $\begin{array}{l}\text { D: Estimated max. \% of } \\
\text { Soy Producers Active in } \\
\text { the Municipality that Were } \\
\text { Surveyed }\left(D=B^{*} C / A\right)\end{array}$ \\
\hline SFA & 30 & 14 & 3 & $140 \%^{2}$ \\
\hline FN & 111 & 15 & 2.1 & $32 \%$ \\
\hline NU & 342 & 14 & 2.2 & $9 \%$ \\
\hline
\end{tabular}

Properties surveyed in SFA were, on average, larger than properties in the other two municipalities (Table 3). Note that these totals are based on the property boundaries according to the datasets described above and do not account for the total landholdings reported by each producer (see results). Producer-reported property sizes were consistently larger than those contained in the property boundary datasets; one reason for this discrepancy may be that producers often consider multiple properties as one unit when planning their land use, which could lead to imprecise recall of the specific dimensions of each property. Respondents were not asked to consult their title or other official property documentation that could confirm the size of each property when completing the survey. The multiple properties used by the producers (as reported in Table 2) were also not included in Table 3, because the additional properties were not georeferenced by the field team and could not be reliably identified using the attributes in the property boundary datasets. 
Table 3. Sizes of properties surveyed.

\begin{tabular}{lcccc}
\hline Municipality & $\begin{array}{c}\text { Avg. Size } \\
\text { of property } \\
\text { Surveyed (ha) }\end{array}$ & $\begin{array}{c}\text { Median Size } \\
\text { of Property } \\
\text { Surveyed (ha) }\end{array}$ & $\begin{array}{c}\text { Avg. Size of } \\
\text { Soy Property } \\
\text { in Municipality (ha) }\end{array}$ & $\begin{array}{c}\text { Median Size of } \\
\text { Soy Property } \\
\text { in Municipality (ha) }\end{array}$ \\
\hline SFA & 9929 & 9778 & 10,693 & 6367 \\
FN & 2934 & 1020 & 1386 & 520 \\
NU & 912 & 866 & 1231 & 500 \\
Total & $\mathbf{4 6 1 1}$ & $\mathbf{1 8 9 6}$ & -- & -- \\
\hline \multicolumn{2}{r}{ Source: calculated by the authors using data from SEMA-MT, Incra, Gibbs, Rausch et al. 2015. }
\end{tabular}

\section{Results: Soy Production and Governance in Mato Grosso}

The findings below first detail examples of property arrangements under which soy is produced in Mato Grosso based on an understanding from extensive fieldwork by the first author that each producer endeavors to leverage the entirety of his or her area-often including multiple owned and rented properties - to best take advantage of market opportunities and to meet the requirements of a matrix of relevant policies. We also describe how soy traders verify potential soy purchases to ensure compliance with the Soy Moratorium and restrictions on trading products from embargoed areas.

\subsection{Use of Multiple Properties by a Single Producer}

The majority (67 percent, or 29 out of 43) of the soy producers surveyed reported more than one property, and they often used a combination of owned and rented properties (see Section 3.2) (Table 4). A typical producer across all municipalities used two or three properties. However, producers in SFA used more properties on average (up to 10) than producers in the other municipalities, which is likely related to the fact that many were corporate producers, who typically have more capital resources than a family farmer. In most cases multiple properties used by the same producer were within the same municipality or in a neighboring municipality, though additional properties were reported as far away as the southern state of Paraná.

Table 4. Multiple property use among soy producers.

\begin{tabular}{lccc}
\hline Municipality & $\begin{array}{c}\text { Max. Number of } \\
\text { Properties Used }\end{array}$ & $\begin{array}{c}\text { Average Number of } \\
\text { Properties Used }\end{array}$ & $\begin{array}{c}\text { \% of Sample Using More } \\
\text { than One Property }\end{array}$ \\
\hline SFA ( $\mathbf{n}=\mathbf{1 4})$ & 10 & 3 & 64 \\
FN ( $\mathbf{n}=\mathbf{1 5})$ & 3 & 2.1 & 60 \\
NU (n= 14) & 5 & 2.2 & 71 \\
Total $(\mathbf{n}=\mathbf{4 3})$ & 10 & 2.4 & 67 \\
\hline
\end{tabular}

The use of multiple properties appears poised to increase over time. Just under half of the producers surveyed indicated that they intend to continue expanding the area they use for soy production in the next two years (44 percent, or 19 out of 43) [41]. At least some portion of the expansion in Mato Grosso is likely to occur on new properties because soy already covers 45 percent of the average soy property and fewer than two percent of soy properties in the Amazon biome had room for legal clearing to make new areas as of 2014 [6]. At the same time, just under half of our respondents ( 20 out of 43 , including 10 of those that do plan to expand) pointed to the low availability of land - either the high price of land, or a lack of land on the market to rent or to buy-as an impediment to expansion [42]. Together, these results suggest that producers who manage to expand are likely to be those with the resources to absorb higher prices for new, previously cleared properties and rentals. 


\subsection{Use of Rental Properties for Soy Production}

Producers reported that renting is an attractive option for expansion because it allows them to keep more capital liquid than purchasing new lands, particularly in areas with rapidly rising land prices such as agricultural frontiers in the Brazilian Amazon [43-45]. Respondents and interviewees in FN and NU reported up to a 20-year payback time on new land purchases. Liquidity is important for producers who see expansion of their areas as an important strategy to mitigate rising costs of soy production [46]. Some respondents also cited that it was difficult to purchase properties that were of interest due to high prices or because the owner was not interested in selling.

We surveyed 17 respondents (40 percent of our sample) who used rental properties for soy production. Producers using rented properties in all three municipalities typically rented and owned within the same municipality. Six of the 17 renters reported using only rented properties and did not own any property on which they planted soy. Most of these rented properties were not used for soy prior to the current producers and were likely previously used as ranches, consistent with the regional land-use history. Those renting reported that they had signed long-term leases of around 10 years. All renters with knowledge about their landlords' current whereabouts reported that the landlord did not purchase new lands to carry on production elsewhere, but instead had reduced or stopped cattle production.

\subsection{Integration of Soy with Cattle Production and Other Crops}

Our survey results also revealed that producers are integrating soy and cattle production systems, especially in SFA. We did not inquire about specific types of integrated systems [47,48]; rather, we simply asked what was produced commercially on each farm and considered concurrent production of soy and cattle to constitute integration in the most basic sense. In most cases we identified, soy and cattle were produced together on the same property and by the same producer (five respondents in SFA, plus one respondent in FN); in two other cases in SFA, a single producer used certain properties for ranching and maintained others only for soy production. The five producers in SFA with same-property soy-cattle integration reported maintaining between 10 and 41 percent of the total productive area of the property as dedicated to pasture, the rest being used for soybean production. Notably, for all respondents producing both cattle and soy, the direction of the shift is from cattle to soy production. We found no evidence in our sample of soy producers taking up cattle ranching.

Double-cropping, or the intra-annual integration of soy production with other crops, typically with corn, is common in agricultural areas throughout Mato Grosso [49]. Of all properties surveyed, 86 percent were producing soy double cropped with corn. Two producers also reported preparing soil for soy production using rice to reduce the natural acidity of the soil, and millet to reduce soil compaction, especially after an area had been used for pasture.

\subsection{Implementation of Private Soy Governance in the Brazilian Amazon}

Soy traders in the Amazon must avoid sourcing from deforested areas to comply with both public and private policies. The traders that we interviewed reported that they check both the list of properties that are found to be out of compliance with the Soy Moratorium and the IBAMA-embargoed list of properties that have been fined for clearing beyond the limits prescribed by the Forest Code to screen or "verify" soy producers according to these policies at the time of purchase [6].

Traders' verification procedures, in turn, are a major component of private governance that guides the land-use decisions of soy producers. Their purchase criteria are a strong incentive for producers to use only compliant areas for soy production. The criteria may also deter deforestation of new areas because they signal to producers that economic returns on newly deforested areas are highly uncertain, especially when a producer is engaged only in soy production. Conversely, because traders' purchase criteria only address deforestation for soy but not for other types of production, it is possible that the soy sector's private governance could result in displacement of activities besides soy into areas 
that do not meet the traders' criteria, potentially resulting in deforestation in any case. However, soy producers are also subject to public policies enforced by public agencies like IBAMA, which discourage any illegal deforestation on all properties and for any purpose.

Indeed, soy producers referred to traders' purchase criteria as a consistent check against deforestation on soy properties, due to property and owner documentation required each year at the time of sale, however minimal. They also reported that Forest Code enforcement by IBAMA and state agencies affected land-use decisions, but this enforcement was also seen as somewhat uneven, both in terms of certainty and in terms of timing. For example, one producer described a perception that IBAMA only targets larger deforestation events, which is consistent with IBAMA's primary reliance on the coarse-resolution DETER rapid alert system for planning enforcement raids [15].

Brazil's soy sector publicizes the methodology of its Soy Moratorium monitoring system, as well as aggregated results for each year, but specific details of the verification process are not publicly shared, including which farms are on the non-compliant list. Likewise, traders consider information about the farms from which soy was purchased or which have their sales blocked to be confidential. However, our interviews with soy producers and employees at silos operated by major traders yielded important insights into the way that soy traders verify purchases in practice. In many cases, the soy buyers had close relationships with producers and these buyers often closely monitored the conditions under which the soy was produced. However, few official documents verifying exactly where the soy was produced and by whom were consistently required at the time of purchase, which may open the door to laundering. For example, even when a producer used multiple properties for production, he or she often provided the trader with documentation about only a single property, which was then compared to the list of non-compliant properties at the time of purchase. Among our respondents, two producers acknowledged selling soy from embargoed areas in the name of a friend or relative. Another producer indicated he also sold all of the soy he produced across several properties using the documents for only one farm simply to reduce paperwork. Producers with embargoes on only part of a property were allowed to sell if they used only the non-embargoed areas for soy production, though representatives of traders did not always visit each property to confirm where production occurred. Both producers and traders also noted that more documentation is required when the producer takes an advance on seeds or other inputs, or in cash, than if he or she simply sells soy to the trader for cash after harvest.

In situations where soy producers used multiple properties, key informants affiliated with government agencies and with soy traders verified that firms could not guarantee that none of the soy they purchased was produced on a property out of compliance with the Soy Moratorium or on an embargoed area without checking all farms used by that producer. In addition, soy traders may unintentionally purchase from properties on the embargo list due to mismatches between the identifying information on the embargo list and the current users of farms [6]. We found evidence of recent crop production on or very near to 13 out of 41 (32 percent) of the embargoed areas we were able to observe in FN. However, we could not confirm soy production due to the timing of our visit outside of the soy-production season nor could we confirm whether traders were buying from these properties because purchase data are not made publicly available. We were unable to look specifically for production on properties found to be out of compliance with the Soy Moratorium because the list is not publicly available (unlike the IBAMA embargoed list).

\section{Discussion: Environmental Governance of Complex Property Arrangements}

Data collected in interviews with farmers and other soy stakeholders have enabled us to characterize property arrangements of soy producers, as well as to document the way that soy-governance systems function on a regular basis in interactions between the soy producer and the soy trader. Here we explore the implications of these findings, using the property arrangements we documented as examples to illustrate potential vulnerabilities in verification procedures used by traders (summarized in Table 5). We explore how these vulnerabilities could provide loopholes for 
non-compliant soy to enter the supply chain if deforestation for soy recommences. We also briefly consider the forest-saving potential of integration of soy and cattle production, as well as the challenges this integration may create for the effectiveness of commodity-specific forest governance in the future.

Table 5. Summary of Property Arrangement Types and Implications for Soy Governance.

\begin{tabular}{|c|c|c|}
\hline $\begin{array}{l}\text { Type of Property } \\
\text { Arrangement }\end{array}$ & Risk for Current Soy Governance & Possible Remedies \\
\hline $\begin{array}{l}\text { Use of } \\
\text { multiple properties }\end{array}$ & $\begin{array}{l}\text { Producers may present documents for one "clean" } \\
\text { property (free of recent deforestation) at the time } \\
\text { they sell soy while continuing production on other } \\
\text { properties with recent deforestation, thereby } \\
\text { laundering soy from non-compliant areas through } \\
\text { a compliant property. }\end{array}$ & $\begin{array}{l}\text { Traders assess all property holdings of } \\
\text { suppliers. Greater transparency } \\
\text { regarding purchases to discourage } \\
\text { producers shopping their "excess" soy } \\
\text { around to multiple traders. }\end{array}$ \\
\hline Use of rentals & $\begin{array}{l}\text { Location of soy production may be especially } \\
\text { difficult to verify; property records and any records } \\
\text { of non-compliance (e.g., IBAMA embargo list) are } \\
\text { especially unlikely to include the name of the } \\
\text { current user. }\end{array}$ & $\begin{array}{l}\text { Discover entire property holdings of } \\
\text { suppliers and assess suppliers' } \\
\text { compliance using geo-referenced } \\
\text { property and embargo information, } \\
\text { not just lists of owners or farm names. }\end{array}$ \\
\hline
\end{tabular}

\subsection{Use of Multiple Properties and Rentals Challenges Verification Systems}

Our results reveal that private governance in the soy sector does not adequately account for the complexity of property ownership in Mato Grosso. For example, producers we surveyed commonly used multiple properties to grow soy, though traders may only thoroughly verify a single property, leaving the compliance of the other properties unverified and opening the door for laundering (selling from "clean" properties that comply with the Soy Moratorium and are free of embargoes, while producing on non-compliant properties). Mismatches between ownership information on IBAMA's list of embargoed properties and the Soy Moratorium blacklist, and other ownership information associated with the property, could lead traders to still inadvertently purchase from areas that should have been disqualified during routine checks of suppliers against these lists, especially if, for example, the property was recently sold (a common reason for name changes on property records). The use of rental properties for soy production exacerbates the risk of purchasing non-compliant soy because traders do not have information about rental properties unless they are declared by producers.

We found that some traders attempted to mitigate the risk generated by multiple-property use by limiting purchases with each producer to the amount of soy that could have been produced on verified properties. However, multiple traders typically operate in each municipality [50], so producers could easily subvert this check by selling up to such a limit to multiple buyers. Traders did apply more safeguards in cases where they financed production, either with cash or following a commonly used practice of providing inputs such as seeds or fertilizer up front, with the future soy harvest serving as collateral. In these cases, they required more detailed information, including copies of additional property ownership documentation and applicable leases to protect their investments. However, producers with multiple properties could use their own capital or other financing to plant on non-compliant properties, thereby avoiding these additional verifications.

Despite these vulnerabilities in the verification systems used by trading firms, the Soy Moratorium's official monitoring system has demonstrated that very little soy was produced on recently cleared land indicating minimal laundering. Indeed, the moratorium's detailed satellite analysis has detected few violations (366 polygons totaling 47,028 ha, or, or 1.57 percent of total Amazon soy area in 2013/2014) [21,22]. The apparent infrequency of laundering thus far could indicate that many producers are not yet aware of loopholes or that the rentals and incidences of multiple property ownership that we discovered are somewhat new or unique to the places we surveyed. 
Risks may also increase as deforestation rates continue to rise in soy-producing regions, especially if a depreciated real or other market shifts increase the profitability of producing soy in Brazil and incentivize larger-scale production [51,52]. Moreover, if the Soy Moratorium monitoring system is ended, traders may rely primarily on the public list of embargoed properties, which only captured about half of the incidences of large-scale deforestation on soy properties in Mato Grosso from 2009 to 2013 [6]. Reliance on the embargo list alone would amplify the risks created by narrow verification procedures and open the door to deforestation for soy entering the supply chain.

\subsection{Soy-Cattle Integration Challenges the Scope of Soy Governance}

Soy traders place firm restrictions on where soy can be grown, but these restrictions do not extend to the parts of soy-producing properties where soy is not grown. Thus, the current scope of the soy supply chain's private governance could protect all forests on a property if the producer was only growing soy because there would be little incentive to work around the agreement by clearing for other purposes [34]. However, when production of soy is integrated with other production systems, narrowly maintaining a clean soy supply chain may limit the impact of soy governance on forest protection overall.

Under the Soy Moratorium, soy producers have continued to clear new areas for reasons other than immediate soy production [6]. Our finding that cattle ranching and soy production are frequently integrated on the same property provides a possible explanation for this trend, which may be described as "on-property leakage." In these cases, producers may maximize use of available properties by grazing cattle on a recently deforested area, although they plant soy in only those areas cleared legally and prior to 2008. Due to inconsistent enforcement of laws limiting deforestation [53,54], some producers apparently find that it is worth the risk to clear new areas even when this clearing is illegal, as long as there are no market consequences. Improvements to environmental governance in the cattle sector could limit such leakage [55], but current policies only apply to some parts of the sector [56]. Soy producers without ranching operations may also clear new areas in expectation of weakening or changing soy governance in the future, or to take up production of another product, though further research is needed to confirm this.

Integration of soy production by cattle ranchers is likely to expand due to declining profitability as the increasingly consolidated meatpacking industry pays lower prices for cattle and pasture recuperation costs remain high [57-59]. The zero-deforestation cattle agreements also add pressure to reduce deforestation and may encourage a turn toward the more profitable co-production of soy [56]. Special lines of financing that support adoption of integrated production systems as a type of lower-carbon production may also make soy an attractive complement to cattle ranching $[48,60]$.

Soy expansion has also been linked to large-scale indirect deforestation following a location rent model, in which a rancher receives a lump sum for a cleared property from an incoming soy farmer, and then uses this money to buy and clear a new, larger area closer to the frontier where property values are lower [61-64]; in this scenario, a policy like the Soy Moratorium that incentivizes exclusive use of older cleared areas for more intensive soy production could strengthen such dynamics. However, opportunities provided by integrated soy and cattle production may be able to help fix ranchers in place and potentially reduce any "amplified" leakage that would otherwise result if soy displaced cattle ranching into larger areas on more distant frontiers [61]. Indeed, recent statistical findings indicate that previous indirect links between soy expansion and forest clearing for new pastures may have been broken by policy changes in the mid-2000s [8]. Relatedly, rentals of former cattle ranches for soy production that we documented may also indicate a shift toward more efficient land use with positive outcomes for forests. When soy producers rent instead of purchase new areas they provide a new type of steady, annual income stream for ranchers dealing with degraded pasture; this rental income may give ranchers an alternative to opening new pastures to continue production elsewhere, or it may simply be insufficient to fund the purchase and clearing of new lands. Areas used for soy for several years may once again be able to support productive pasture, so ranchers may plan 
return to raising cattle on their old properties at the end of the lease. Thus, the type of cattle-soy transition that we observed may be less likely to incentivize the clearing of frontier areas than would receipt of a lump sum, which is the type of transaction typically assumed in models that find soy expansion to be indirectly responsible for deforestation in frontier regions in the Amazon $[63,64]$. Cattle ranchers who have integrated soy production may also now be recovering degraded pasture instead of abandoning it for new areas, as they might have in the past. However, further research is needed to better understand these dynamics.

\subsection{Strengths and Weaknesses of Private Environmental Governance}

Brazil's soy sector typifies private sector environmental governance regimes because of the important role that globally positioned commodity traders play in enforcing environmental norms. Although soy traders are also responding to legal obligations when they check the embargoes list, they also derive authority for limiting from whom they will purchase soybeans from their consumers, via the (global) market [65].

Proponents of private governance point to its efficiency [24]. Arguably, traders' responsibility for monitoring and verification systems allows them to incentivize deforestation-free soy production more rapidly and more effectively than would public enforcement efforts alone. Though enforcement of environmental laws has been improving in Brazil, contributing to the rapid reduction in Amazon deforestation since mid-2000s $[9,59,66]$, interested land users have continued to be able to take advantage of weaknesses in enforcement including delays in the issuance of embargoes for illegal deforestation and low rates for collecting environmental fines [54]. Indeed, the presence of commodity traders in nearly every soy-producing municipality in the Amazon, their frequent interaction with producers, and their nearly complete control of market access for soybeans make these companies among the most influential actors in the Amazon [6,67].

Despite the proven track record of private soy governance over the last decade, we identified potential loopholes in the current governance arrangements, particularly in the verification processes used by soy traders. We also highlighted the growing trend of soy-cattle integration, which could mean that soy producers will increasingly clear forest for cattle grazing; this clearing is not checked by traders under current private soy governance, so acceleration of such a trend could reduce the impact for forests of soy-specific governance [61,68-70]. When the Soy Moratorium is lifted and its monitoring system discontinued, possibly as soon as May 2016 [71], the amount of information available to traders about deforestation on soy properties could diminish considerably, increasing the risk of purchasing soy associated with deforestation and changing the signals traders are able to send to producers about acceptable land-use practices. Finally, neither spatially explicit Soy Moratorium monitoring results, nor traceability data about purchasing decisions are publicly available. This lack of transparency makes it difficult for third parties to verify adherence with the moratorium, or to quantify and track the fate of non-compliant soy, which could enter the supply chain through laundering [68,69].

\section{Conclusions and Considerations for Future Soy Governance}

Today, very little soy is grown on recently deforested areas in the Brazilian Amazon, and the Amazon soy sector is now used as a model for changes in environmental governance for other supply chains [47,48]. However, recent increases in deforestation rates in soy-producing regions such as the state of Mato Grosso suggest that even apparently effective policies may need to be reevaluated and become more adaptive to evolving production scenarios [5,51]. Soy traders play an active role in the routine application of environmental policy by verifying that properties from which soy is purchased are compliant with the Soy Moratorium and are free of embargoes. The property arrangements we have documented suggest that truly guaranteeing deforestation-free soy purchases in the long term will require that soy buyers discover and monitor the entire extent of their suppliers' landholdings, in spite of the burden that such efforts could entail for traders, especially if public governance efforts are not also significantly improved. 
A well-designed traceability system could transparently communicate indefinite and comprehensive surveillance of land-use practices to producers while also improving the ability of industry actors to articulate the effectiveness of their commitments, and for consumers to verify industry claims [72]. Such an approach could incentivize continued compliance by producers, leading to more significant overall reductions in deforestation [73]. In fact, a public registry of soy purchases by farm could support traders' current efforts of setting limits on sales by a single producer to reduce the probability of purchasing non-compliant soy. However, such a system would be challenging to implement due to concerns about sensitive business information and producer confidentiality.

An important challenge for improving verification procedures is the lack of a comprehensive and transparent geo-database of all properties and their owners in Brazil. The environmental licensing requirement known as CAR, required by federal forest law, could help fill this gap, but significant challenges must first be overcome. For example, overlaps and disputed areas within the properties already in the database need to be resolved [74], a process which will likely take some time. Currently, public access to the database is uncertain as well, which could limit traders' efforts to map their full supply chains, as well as the ability of third parties such as certification firms or NGOs to conduct the kinds of audits that often increase the credibility of corporate sustainability initiatives [23]. Resolving these challenges will require significant support from the Brazilian government to improve the CAR, including ensuring its role in the "transparency regime" of other reliable and publicly available data about the Amazon [75]. However, there is no registry documenting property rentals, so even a complete and fully accessible CAR would not provide all of the information needed to fully verify soy purchases.

Additionally, current soy governance should be expanded to better account for the growing importance of soy-cattle integration and address possible on-farm leakage, although the challenges of governing land use on the entire farm are significant. For example, many soy farms in Mato Grosso (25 percent, or 851 out of 3463 as of 2014) would be blocked from selling to major traders if any recent deforestation on the farm rendered the property non-compliant [6], which would significantly reduce an important supply of soy for traders. In fact, the narrow scope of the Soy Moratorium has likely contributed to its decade-long persistence. Alternatively, strengthening official enforcement against illegal deforestation overall could reduce the role and responsibility of for-profit actors in ensuring that the sector does not drive deforestation, reducing the importance of expanding the scope of private soy governance. This option is endorsed by leaders in Brazil's soy industry [31], though it is unlikely that state-led governance will be able to effectively replace or improve on the current private-sector governance in the near future [6,51].

The soy industry has been lauded for its rapid and effective efforts to reduce its role in deforestation in the Brazilian Amazon, raising hopes for the role that environmental governance oriented around supply chains can play in forest protection. The diverse and complex property arrangements on which soy is produced underscore the importance of both robust monitoring and robust verification procedures to keep the supply chain free of deforestation. Producers must navigate increasingly complex and sometimes conflicting incentives to expand their production, to integrate multiple types of production for economic and agronomic reasons, and to leave forests standing, among others. Given these trends, appropriate adaptations to commodity-specific approaches to deforestation-free supply chains would better position this kind of governance to help protect forests in the long term.

Acknowledgments: The authors are grateful to Jessica L'Roe, Annabel Ipsen, Ian Schelly, Matthew Christie, Jacob Munger, Fanny Moffette, and Tyler Lark for their discussion and insightful suggestions on previous versions of this manuscript, and to three anonymous reviewers whose comments greatly improved the final version. Additionally, Ian Schelly provided valuable assistance preparing maps for use in the field, and Pedro Lopes Miranda, Jr. and Dylan Murray played crucial roles in the collection of the field-based data cited in this paper. Finally, the authors are extremely grateful for financial support from the Gordon and Betty Moore Foundation and from the Norwegian Agency for Development Cooperation's Department for Civil Society under the Norwegian Forest and Climate Initiative. 
Author Contributions: Lisa L. Rausch and Holly K. Gibbs both contributed to the research design. Lisa L. Rausch collected field data, and Lisa L. Rausch and Holly K. Gibbs undertook analysis of spatial datasets. Lisa L. Rausch undertook preparation of the manuscript with valuable contributions, revisions, and critical reviews from Holly K. Gibbs from the draft to the final stages of the paper.

Conflicts of Interest: The authors declare no conflict of interest.

\section{References and Notes}

1. Conab [National Food Supply Company]. Série Histórica Soja. Available online: http://www.conab.gov.br/ conteudos.php?a=1252\& (accessed on 19 October 2015).

2. IBGE [Brazilian Institute of Geography and Statistics]. Contas Regionais do Brasil. Available online: http://www.ibge.gov.br/home/estatistica/economia/contasregionais/2012/default_xls_1995_2012.shtm (accessed on 2 September 2015).

3. Richards, P.; Pellegrina, H.; VanWey, L.; Spera, S. Soybean Development: The Impact of a Decade of Agricultural Change on Urban and Economic Growth in Mato Grosso, Brazil. PLoS ONE 2015. [CrossRef] [PubMed]

4. Morton, D.C.; DeFries, R.S.; Shimabukuro, Y.E.; Anderson, L.O.; Arai, E.; del Bon Espirito-Santo, F.; Freitas, R.; Morisette, R. Cropland expansion changes deforestation dynamics in the southern Brazilian Amazon. Proc. Natl. Acad. Sci. USA 2006, 103, 14637-14641. [CrossRef] [PubMed]

5. INPE [National Institute of Spatial Research] Projeto PRODES: Monitoriamento da Floresta Amazônica Brasileira por Satélite. Available online: http://www.obt.inpe.br/prodes/index.php (accessed on 2 September 2015).

6. Gibbs, H.K.; Rausch, L.; Munger, J.; Schelly, I.; Morton, D.C.; Noojipady, P.; Soares-Filho, B.; Barreto, P.; Micol, L.; Walker, N.F. Brazil's Soy Moratorium. Science 2015, 347, 377-378. [CrossRef] [PubMed]

7. Macedo, M.N.; DeFries, R.S.; Morton, D.C.; Stickler, C.M.; Galford, G.L.; Shimbukuro, Y.E. Decoupling of deforestation and soy production in the southern Amazon during the late 2000s. Proc. Natl. Acad. Sci. USA 2012, 109, 1341-1346. [CrossRef] [PubMed]

8. Gollnow, F.; Lakes, T. Policy change, land use, and agriculture: The case of soy production and cattle ranching in Brazil, 2001-2012. Appl. Geogr. 2014, 55, 203-211. [CrossRef]

9. Nepstad, D.C.; McGrath, D.; Stickler, C.; Alencar, A.; Azevedo, A.; Swette, B.; Beterra, T.; DiGiano, M.; Shimada, J.; da Motta, R.S.; et al. Slowing Amazon deforestation through public policy and interventions in beef and soy supply chains. Science 2014, 344, 1118-1123. [CrossRef] [PubMed]

10. Garrett, R.D.; Rausch, L.L. Green for gold: Social and ecological tradeoffs influencing the sustainability of the Brazilian soy industry. J. Peasant Stud. 2015. [CrossRef]

11. Soler, L.S.; Verburg, P.H.; Alves, D.H. Evolution of land use in the Brazilian Amazon: From frontier expansion to market chain dynamics. Land 2014, 3, 981-1014. [CrossRef]

12. Government of Brazil. Plano de Ação para a Prevenção e Controle do Desmatamento na Amazônia Legal. Available online: http://www.fundoamazonia.gov.br/FundoAmazonia/export/sites/default/ site_pt/Galerias/Arquivos/Publicacoes/PPCDAM.pdf (accessed on 2 September 2015).

13. Soares-Filho, B.; Rajao, R.; Macedo, M.; Carneiro, A.; Costa, W.; Coe, M.; Rodrigues, H.; Alencar, A. Cracking Brazil's forest code. Science 2014, 344, 363-364. [CrossRef] [PubMed]

14. IBAMA [Brazilian Institute of Environment and Renewable Natural Resources]. Public Consultation of Environmental Charges and Embargoes. Available online: https://servicos.ibama.gov.br/ctf/publico/ areasembargadas/ConsultaPublicaAreasEmbargadas.php (accessed on 19 October 2015).

15. Rajão, R.; Vurdubakis, T. On the pragmatics of inscription: Detecting deforestation in the Brazilian Amazon. Theory Cult. Soc. 2013, 30, 151-177.

16. Nepstad, D.C.; Stickler, C.M.; Almeida, O.T. Globalization of the Amazon soy and beef industries: Opportunities for conservation. Conserv. Biol. 2006, 20, 1595-1603. [CrossRef] [PubMed]

17. DeFries, R.; Herold, M.; Verchot, L.; Macedo, M.N.; Shimabukuro, Y. Export-oriented deforestation in Mato Grosso: harbinger or exception for other tropical forests? Philos. Trans. R. Soc. B 2013. [CrossRef] [PubMed]

18. Bolwig, S.; Ponte, S.; de Toit, A.; Riisgaard, L.; Halberg, N. Integrating poverty and environmental concerns into value-chain analysis: A conceptual framework. Dev. Policy Rev. 2010, 28, 173-194. [CrossRef]

19. Greenpeace. Eating up the Amazon. Available online: http://www.greenpeace.org/usa/research/eatingup-the-amazon/ (accessed on 2 September 2015). 
20. ABIOVE [Brazilian Association of Vegetable Oil Industries]. Soy Moratorium. Available online: http://www.abiove.org.br/site/index.php?page=soy-moratorium\&area=MTEtMy0x (accessed on 2 September 2015).

21. GTS [Soybean Working Group]. Soy Moratorium: Seventh Year of Mapping and Monitoring Soybean Acreage in the Amazon Biome. Available online: http://www.abiove.org.br/site/_FILES/ English/12122014-113940-24.11.2014._relatorio_da_moratoria_da_soja_versao_ingles.pdf (accessed 2 September 2015).

22. Rudorff, B.F.T.; Adami, M.; Aguiar, D.A.; Moreira, M.A.; Mello, M.P.; Fabiani, L.; Amaral, D.F.; Pires, B.M. The Soy Moratorium in the Amazon Biome Monitored by Remote Sensing Images. Remote Sens. 2011, 3, 185-202. [CrossRef]

23. McAllister, L.K. Sustainable consumption governance in the Amazon. Environ. Law Report. 2008, 38, 10873-10881.

24. Seto, K.C.; Reenberg, A.; Boone, C.G.; Fragkias, M.; Haase, D.; Langanke, T.; Marcotullio, P.; Munroe, D.K.; Olah, B.; Simon, D. Urban land teleconnections and sustainability. Proc. Natl. Acad. Sci. USA 2012, 109, 7687-7692. [CrossRef] [PubMed]

25. SECEX [Secretary of International Commerce]. System of Analysis of Foreign Trade. Available online: http:/ /aliceweb.desenvolvimento.gov.br (accessed on 19 October 2015).

26. Newton, P.; Agrawal, A.; Wollenberg, L. Enhancing the sustainability of commodity supply chains in tropical forest and agricultural landscapes. Glob. Environ. Chang. 2013, 23, 1761-1772. [CrossRef]

27. Loureiro, M.L.; Lotade, J. Do fair trade and eco-labels in coffee wake up the consumer conscience? Ecol. Econ. 2005, 53, 129-138. [CrossRef]

28. Smith, B.G. Developing sustainable food supply chains. Phil. Trans. R. Soc. B 2008, 363, 849-861. [CrossRef] [PubMed]

29. Eden, S.; Bear, C.; Walker, G. Mucky carrots and other proxies: Problematising the knowledge-fix for sustainable and ethical consumption. Geoforum 2008, 39, 1044-1057. [CrossRef]

30. Gibbon, P. Upgrading primary production: A global commodity chain approach. World Dev. 2001, 29, 345-363. [CrossRef]

31. ABIOVE [Brazilian Association of Vegetable Oil Industries]. New agenda for soybeans in the Amazon biome. Available online: http://www.abiove.org.br/site/_FILES/English/27022014-08525727_02_2014_pdf_new_agenda_for_soybeans_in_the_amazon_biome.pdf (accessed on 2 September 2015).

32. FEFAC [European Feed Manufacturers Federation] Soy Moratorium in Brazil Enters Transition Period until 31 May 2016 in Order to Strengthen Implementation of both the CAR and Consolidated Partnerships with Environmental State Secretariats. Available online: http://www.fefac.eu/ news.aspx?CategoryID=2094\&EntryID=18783 (accessed on 2 September 2015).

33. United Nations. New York Declaration on Forests. Available online: http://www.un.org/climatechange/ summit/wp-content/uploads/sites/2/2014/07/New-York-Declaration-on-Forest-\%E2\%80\%93-ActionStatement-and-Action-Plan.pdf (accessed on 10 February 2016).

34. Brannstrom, C.; Rausch, L.; Brown, J.C.; de Andrade, R.M.T.; Miccolis, A. Compliance and market exclusion in Brazilian agriculture: Analysis and implications for "soft" governance. Land Use Policy 2012, 29, 357-366. [CrossRef]

35. IBGE [Brazilian Institute of Geography and Statistics]. Pesquisa Agrícola Municipal. Available online: http://www.sidra.ibge.gov.br/ (accessed on 10 February 2016).

36. Sanches, R.A.; Villas-Bôas, A. Planejando a gestão em um cenário socioambiental de mudanças: O caso da bacia do rio Xingu. Revista de Administração Público 2005, 39, 365-380.

37. MMA [Ministry of the Environment, Brazil]. Lista de Municípios Prioritários da Amazônia. Available online: http:/ / www.mma.gov.br/florestas/controle-e-preven\%C3\%A7\%C3\%A3o-do-desmatamento/planode-a $\%$ C3\%A7\%C3\%A3o-para-amaz $\% C 3 \% B 4$ nia-ppcdam/lista-de-munic $\% C 3 \% A D p i o s-p r i o r i t \% C 3 \% A 1$ riosda-amaz\%C3\%B4nia (accessed on 30 June 2015).

38. Onwuegbuzie, A.J.; Collins, K.M.T. A Typology of Mixed Methods Sampling Designs in Social Science Research. The Qualitative Report 2007, 12, 281-316.

39. SEMA-MT [State Secretary of the Environment-Mato Grosso]. Sistema Integrado de Monitoramento e Licenciamento Ambiental-Mato Grosso (SIMLAM-MT). Available online: http:/ / monitoramento.sema.mt.gov.br/simlam/ (accessed on 1 March 2014). 
40. INCRA [National Institute of Colonization and Agrarian Reform]. Certificado de Cadastro do Imóvel Rural (CCIR). Available online: https: / / acervofundiario.incra.gov.br (accessed on 1 July 2014).

41. Sixteen respondents said they wanted to expand to increase their profits, 2 wanted to improve pasture, and 1 did not answer.

42. Other reasons cited included environmental factors such as changes in rainfall or pests (3); that infrastructure was too poor (4); insufficient access to adequate technical support (3); and 23 respondents cited difficulties expanding while complying with deforestation rules (responses were not mutually exclusive). Some producers sought alternate solutions; one respondent said his solution to high land prices would be to invest in silos and drying services instead of expansion of his area in the future.

43. FGV [Fundaçao Getulio Vargas]. Preços de Venda e Arrendamento de Terras. Available online: http:/ / portalibre.fgv.br/main.jsp?lumChannelId=402880811D8E34B9011D92B8C944175A (accessed on 16 April 2014).

44. Saur, S.; Leite, S.P. Agrarian structure, foreign investment in land, and land prices in Brazil. J. Peasant Stud. 2012, 39, 873-898. [CrossRef]

45. Sills, E.O.; Cavigilia-Harris, J.L. Evolution of the Amazonian frontier: Land values in Rondônia, Brazil. Land Use Policy 2008, 26, 55-67. [CrossRef]

46. Vera-Diaz, M.d.C.; Kaufmann, R.K.; Nepstad, D.C.; Schesinger, P. An interdisciplinary model of soybean yield in the Amazon Basin: The climatic, edaphic, and economic determinants. Ecol. Econ. 2008, 65, 420-431. [CrossRef]

47. Balbino, L.C., Barcellos, A.O., Stone, L.F., Eds.; Reference Document Crop-Livestock-Forestry Integration; Embrapa: Brasilia D.F., Brazil, 2011; p. 135.

48. Gil, J.; Siebold, M.; Berger, T. Adoption and Development of integrated crop-livestock-forestry systems in Mato Grosso, Brazil. Agric. Ecosyst. Environ. 2015, 199, 394-406. [CrossRef]

49. VanWey, L.K.; Spera, S.; de Sa, R.; Mahr, D.; Mustard, J.F. Socioeconomic development and agricultural intensification in Mato Grosso. Phil. Trans. R. Soc. B 2013. [CrossRef] [PubMed]

50. Garrett, R.D.; Lambin, E.F.; Naylor, R.L. The new economic geography of land use change: Supply chain configurations and land use in the Brazilian Amazon. Land Use Policy 2013, 34, 265-275. [CrossRef]

51. Fearnside, P.M. Environment: Deforestation soars in the Amazon. Nature 2015, 521, 423. [CrossRef] [PubMed]

52. Gudynas, E. The new Bonfire of Vanities: Soybean cultivation and globalization in South America. Development 2008, 51, 512-518. [CrossRef]

53. Börner, J.; Wunder, S.; Wertz-Kanounnikoff, S.; Hyman, G.; Nascimento, N. Forest law enforcement in the Brazilian Amazon: Costs and income effects. Glob. Environ. Chang. 2014, 29, 294-305.

54. Verburg, R.; Rodrigues Filho, S.; Lindoso, D.; Debortoli, N.; Litre, G.; Bersztyn, M. The impact of commodity price and conservation policy scenarios on deforestation and agricultural land use in a frontier area within the Amazon. Land Use Policy 2014, 37, 14-26. [CrossRef]

55. Pacheco, P.; Poccard-Chapuis, R. The complex evolution of cattle ranching development amid market integration and policy shifts in the Brazilian Amazon. Ann. Assoc. Am. Geogr. 2012, 102, 1366-1390.

56. Gibbs, H.K.; Munger, J.; L'Roe, J.; Barreto, P.; Pereira, R.; Christie, M.; Amaral, T.; Walker, N.F. Did Ranchers and Slaughterhouses Respond to Zero-Deforestation Agreements in the Brazilian Amazon? Conserv. Lett. 2015. [CrossRef]

57. Walker, N.F.; Patel, S.A.; Kalif, K.A.B. From Amazon pasture to the high street: deforestation and the Brazilian cattle product supply chain. Tropical Conservation Sci. 2013, 6, 446-467.

58. Smeraldi, R.; May, P. A hora da conta: Pecuária, Amazônia, e Conjuntura. Amigos da Terra. Available online: http:/ / commodityplatform.org/wp/wp-content/uploads/2009/05/a-hora-da-conta.pdf (accessed on 19 October 2015).

59. Assunção, J.; Gandour, C.; Rocha, R. Deforestation Slowdown in the Legal Amazon: Prices or Policies? Available online: http://climatepolicyinitiative.org/wp-content/uploads/2012/03/DeforestationPrices-or-Policies-Working-Paper.pdf (accessed on 19 October 2015).

60. Observatório ABC. Agricultura de Baixa Emissão de Carbono: Financiando a Transição. Available online: http:/ / www.observatorioabc.com.br/agricultura-de-baixa-emissao-de-carbono-financiando-a-transicao? locale $=$ pt-br (accessed on 4 November 2015).

61. Gasparri, N.I.; le Polain de Waroux, Y. The coupling of South American soybean and cattle production frontiers: New challenges for conservation policy and land change science. Conserv. Lett. 2014. [CrossRef] 
62. Walker, R.; Richards, P. The ghost of Von Thünen lives; A political ecology of the disappearance of the Amazonian rainforest. In Land Change Science, Political Ecology, and Sustainability: Synergies and Divergences; Brannstrom, C., Vadjunec, J.M., Eds.; Routledge: New York, NY, USA, 2014; pp. $24-47$.

63. Arima, E.Y.; Richards, P.; Walker, R.; Caldas, M.M. Statistical confirmation of indirect land use change in the Brazilian Amazon. Environ. Res. Lett. 2011, 6. [CrossRef]

64. Barona, E.; Ramankutty, N.; Hyman, G.; Coomes, O.T. The role of pasture and soybean in deforestation of the Brazilian Amazon. Environ. Res. Lett. 2010, 5. [CrossRef]

65. Cashore, B. Legitimacy and the Privatization of Environmental Governance: How Non-state market-driven (NSMD) governance systems gain rule-making authority. Governance 2002, 15, 503-529. [CrossRef]

66. Arima, E.Y.; Barreto, P.; Araújo, E.; Soares-Filho, B. Public policies can reduce tropical deforestation: Lessons and challenges from Brazil. Land Use Policy 2014, 41, 465-473. [CrossRef]

67. Brown, J.C.; Koeppe, M. Debates in the environmentalist community: The soy moratorium and the construction of illegal soybeans in the Brazilian Amazon. In Environment and the Law in Amazonia: A Plurilateral Encounter; Cooper, J.M., Hunefeldt, C., Eds.; Susex Academic Press: Brighton, UK, 2013; pp. 110-126.

68. Baletti, B. Saving the Amazon; Sustainable soy and the new extractivism. Environ. Plan. A 2014, 46, 5-25. [CrossRef]

69. Elgert, L. 'More soy on fewer farms' in Paraguay: Challenging neoliberal agriculture's claims to sustainability. J. Peasant Stud. 2015. [CrossRef]

70. Wilkinson, J. From fair trade to responsible soy: Social movements and the qualification of agrofood markets. Environ. Plan. A 2011, 43, 2012-2026. [CrossRef]

71. Greenpeace. Moratória da soja é renovada para fortalecer governança na Amazônia; 25 November 2014. Available online: http://www.greenpeace.org/brasil/pt/Noticias/Moratoria-da-soja-e-renovada-parafortalecer-governanca-na-Amazonia/ (accessed 10 February 2016).

72. Mol, A.P.J. Environmental governance in the Information Age: The emergence of informational governance. Environ. Plan. C: Gov. Policy 2006, 24, 497-514. [CrossRef]

73. Lambin, E.F.; Meyfroidt, P.; Rueda, X.; Blackman, A.; Börner, J.; Cerutti, P.O.; Dietsch, T.; Jungmann, L.; Lamarque, P.; Lister, J.; et al. Effectiveness and synergies of policy instruments for land use governance in tropical regions. Global Environ. Chang. 2014, 28, 129-140. [CrossRef]

74. Pires, M.O.; Ortega, V.G. O Cadastro Ambiental Rural na Amazônia. Conservation International. Available online: http://inovacar.org.br/uploads/documents/O\%20Cadastro\%20Ambiental\%20Rural\%20na\% 20Amazonia..pdf (accessed on 3 September 2015).

75. Rajão, R.; Georgiadou, Y. Blame games in the Amazon: Environmental crises and the emergence of a transparency regime in Brazil. Glob. Enviorn. Politics 2014, 14, 97-115. [CrossRef] 